\title{
SZOLGÁLTATÁSMARKETING: MÚLT VAGY JÖVŐ?
}

A 2000-es évek elején jelentős paradigmaváltás volt tapasztalható a szolgáltatásmarketing területén. Többen feltették a kérdést: vajon van-e értelme a jövőben szolgáltatásmarketingről beszélni? Ennek a kérdésnek a kapcsán szeretnék a szerzők bemutatni, hogy milyen tényezők, milyen változások játszottak szerepet abban, hogy ezt a kérdést a téma kutatói egyáltalán megfogalmazták, s vajon ténylegesen van-e értelme a továbbiakban megkülönböztetni, s önálló témaként beszélni a szolgáltatások marketingtevékenységéről. A dolgozatban először bemutatják a szolgáltatásmarketing elmúlt évtizedének fejlődési tendenciáit, kiemelve ezek közül a technológia és az élményközpontúság szerepét, majd bemutatnak egy jövőbe mutató témát, a jóllét elősegítését célzó, transzformatív szolgáltatáskutatást, amely véleményük szerint kiemelt hangsúlyt kell, hogy kapjon mind a nemzetközi, mind a hazai kutatásokban is.

\section{Kulcsszavak: szolgáltatásmarketing, marketingkutatás, transzformatív szolgáltatáskutatás}

2 004-ben egymástól függetlenül két-két nagyhatású szolgáltatáskutató (Vargo - Lusch, 2004a; Lovelock - Gummeson, 2004) jelentette meg gondolatait, amelyek lényegében azt a kérdést feszegették, hogy van-e relevanciája a jövőben a szolgáltatásmarketingnek, szükséges-e különálló témakörként kezelni. Mondandójuk apropóját egyrészt az a tény adta, hogy a 2000-es évekre a fejlett országok GDP-jének jelentős része (jellemzően több mint 2/3-a) a szolgáltatóágazatból származott, másrészt az a folyamat, amely alapján úgy tünik, a megfogható termékek világában is egyre nagyobb teret kapnak a szolgáltatások. Míg 1977-ben Shostack (1977) a Journal of Marketingben a „Breaking free from Product Marketing” tematikával publikálta gondolatait, addig 2004-ben ugyanebben a lapban Vargo és Lusch (2004a) egy új paradigma megjelenését jelentette be, amelyet ők a „szolgáltatás-domináns logika” (SDL) névvel illettek. Akárcsak Shostack cikke a maga idejében, Vargo és Lusch gondolatai is nagy hatással voltak a szolgáltatásmarketing kutatására. Elméletük legfontosabb kiindulópontja, hogy a termékeket (legyenek azok megfoghatóak vagy megfoghatatlanok) az értékteremtés oldaláról vizsgálják. Cikkükben választ adnak arra, hogy az új logika szerint hogyan teremt értéket a vállalat, a fogyasztó és az őket körülvevő piaci szereplök együttmüködése. Ezen elv szerint nem a vállalati értékteremtést kell az üzleti stratégia középpontjába állítani, hanem a közös értékteremtést. A vállalat ebben az értelmezésben nem értékteremtő, pusztán csak segítője az értékteremtésnek, amely értéket valójában a vevő állítja elö. Mindazon erőforrások tehát, amelyek elősegítik a közös értékteremtést, versenyelőnyt jelentenek a vállalatok számára. Vitaindító cikkükben Vargo és Lusch (2004a) nyolc FP-t, azaz nyolc alapvetést állítottak fel, amelyet később kiegészítettek tízre (Vargo- Lusch, 2008), majd 2016-ban hozzáfüztek még egyet (Vargo - Lusch, 2016). Ezek közül számunkra most a legizgalmasabb az ötödik: „Minden gazdaság szolgáltatásgazdaság". Hasonló következtetésre jutott Lovelock és Gummeson (2004), amikor egyik végkövetkeztetésük szerint a szolgáltatásmarketing „legyőzte” a termékek marketingjét, és mostanra átvette az általános marketing szerepét. Ugyanezt Vargo és Lusch a nyolcadik alapvetésükben így fogalmazzák meg: „A szolgáltatás-központú gondolkodásmód vevőorientált és kapcsolati”.

Felmerül a kérdés, hogy mit jelent mindez a szolgáltatásmarketing számára? Vajon tényleg el kell-e felejteni a szolgáltatások alapvető jellemzőit (HIPI), és az ehhez kapcsolódó speciális szolgáltatásmarketing-eszközöket (Vargo - Lusch, 2004b)? Véleményünk szerint az azóta eltelt évek arra adnak bizonyítékot, hogy éppen fordítva: ezek az eszközök a termékek világában is értelmet nyernek, és alakítják a marketinggondolkodást. A megoldás tehát nem az, hogy elvetjük azokat a jellemzőket és eszközöket, amelyeket hagyományosan a szolgáltatások esetében használunk, hanem megpróbáljuk alkalmazni őket a termékek világában is. Fisk és Grove (2010) szóhasználatával élve azt is mondhatjuk, hogy a marketinggondolkodás átvette a szolgáltatásmarketing „nyelvezetét”, és mára kifejlődött az a közös nyelvezet, amely a szolgáltatáskutatás során alakult ki, de elfogadott és „,megértett” mindkét világban. Röviden összefoglalva és csak egy-egy példával megvilágítva, ez a következőket jelentheti:

A megfoghatatlanság mint alapvető szolgáltatásjellemző ugyan megnehezítheti a megfogható elemeken keresztül történő kommunikálást, másrészről azonban könnyebben lehet a képzettársításokon keresztül kommunikálni. A képzettársítások ereje rendkívül fontos, sokszor jobban emlékeznek a fogyasztók egy-egy jó asszociációra, mint a termékek megfogható, objektív tulajdonságaira. A következő jellemző a heterogenitás, a változékonyság. Ami a szolgáltatások számára természetes, azaz hogy minden egyes teljesítés eltérő lehet a vevői inputok, az adott vevői kívánságokat kiszolgáló folyamatok és a kiszolgáló személy különbözősége miatt, az mára úgy tűnik egyfajta vágyott eredmény a megfogható terméket gyártók számára. A tömeges testre szabás, sőt az ,egyedi tömegtermelés” (customerising: Wind - Rangaswamy, 2001; co-creation: Prahalad - Ramaswamy, 2004) mint például a Nike cipői vagy a Dell számítógépei az erre vonatkozó klasszikus 
példái ennek a jelenségnek, ami úgy tünik mára a vevők és a gyártók részéről is elfogadottá vált. A szolgáltatások számára levonható következtetés mindebből, hogy érdemes fenntartani a szolgáltatások heterogenitását, változékonyságát, hiszen ez addicionális értéket adhat a vevőnek, s csak ott kell a standardizálással foglalkozni, ahol annak a vevő számára értékelhető előnye származik. Tehát valóban igaz, amit az előbbiekben a nyolcadik alapvetés során állítottunk: a szolgáltatásközpontú gondolkodás vevőorientált. Azaz a vevői igény kell, hogy meghatározza, hogy mit érdemes standardizálni, nem pedig a vállalati müködés hatékonysága.

Mindebböl következik, hogy a vevőnek valójában ott kell lennie a helyszínen, azaz nem szétválasztani kell az előállítást a fogyasztástól, hanem éppen minél közelebb hozni. Hány termelővállalat örülne, ha minden vásárlás alkalmával találkozhatna a vevőivel! Külön erőfeszítést tesznek azért (pl. social media marketing), hogy interakciót kezdeményezzenek a vásárlóikkal. A szolgáltatók számára ez evidencia, hiszen a hagyományos szolgáltatások esetében a vevő valamilyen módon közvetlen kapcsolatba kell, hogy lépjen szolgáltatójával. A megoldást tehát nem a sok esetben tapasztalható „ki a vevővel a szolgáltató gyárból" elve jelenti, hanem éppen annak a lehetőségnek a maximális kihasználása, hogy a vevő ott van a helyszínen, akár fizikailag, akár szellemileg, kapcsolatba tudunk vele lépni, ismerjük, tudunk vele közvetlenül kommunikálni. Az elmúlt évtizedekben a bankokra például az volt a jellemző, hogy megpróbálták az ügyfeleket minél jobban eltávolítani a bankfiókokból, felkínálva számukra akár telefonos, akár internetes kapcsolattartási lehetőségeket. Mára úgy tünik, mindez túl jól sikerült: bizonyos célcsoportok teljesen leszoktak a bankfiókról, ennek következtében a bank nem tud velük személyesen találkozni, így a kötődésnek egy fontos elemét veszítették el, a személyes kötődést. A mai bankreklámokban már éppen arról próbálják meggyőzni az ügyfelet, hogy térjenek be a bankfiókba, ahol személyes kiszolgálást és törődést kaphatnak. Nagyon is reális ez az új irány, hiszen mi tud jobban hatni, mint a személyes kapcsolat.

$\mathrm{S}$ végül a negyedik klasszikus szolgáltatásjellemző a tárolhatatlanság is megjelenik a termelővállalatoknál, amennyiben akár a divat, akár a romlandóság, akár hatékonysági kritériumok miatt érdemes minimalizálni a rendelési mennyiséget, és a lehető legrövidebb rendelési időkkel dolgozni (ECR, JIT-rendszerek). Mindez előrevetíti a szolgáltatásoknál jól ismert kereslet és kínálat elörejelzésének és menedzselésének kérdését, amelyre egyre szofisztikáltabb válaszokat adnak a szolgáltatóvállalatok (pl. dinamikus árképzés).

A szolgáltatásdomináns marketinggondolkodás az elmúlt évtizedben mind a tudományos szakcikkek, mind a gyakorlati élet valóságos marketingtevékenységében szerepet kapott, amit jelez például hogy Kelemenné (2014) közforgalmú közlekedésre alkalmazza, míg Berács (2006) az oktatásra. A szolgáltatáslogika termelővállalatok életében betöltött növekvő szerepével kapcsolatosan az utóbbi években két jelentősebb irányzat jelent meg, az egyik a szolgálatosodás (servitization), a másik pedig a szolgálta- tásbeáramlás (service infusion). Mindkét irányzat alapvetése, hogy a termelővállalatok egyre inkább a szolgáltatások bevezetésével versenyeznek, így a versenyelőnyök sokszor az addicionális szolgáltatásokból erednek. Míg a szolgálatosodás kutatói elsősorban a termék-szolgáltatás rendszerek vizsgálatát és kialakulásának lehetőségeit tartják szem előtt (Pawar et al., 2009; Demeter, 2010; Demeter - Szász, 2012; Bálint, 2014), addig a szolgáltatásbeáramlás kutatói (Zeithaml et al., 2014) arra hívják fel a figyelmet, hogy a szolgáltatásnövekedés mára iparágakon és országhatárokon átívelő stratégia, és a fejlődés egyetlen lehetősége a termelővállalatok számára. Mindez azonban csak akkor tud sikeressé válni, ha a vállalat elfogadja a szolgáltatásmarketing eszközeit, és az alapvetően termékorientációjú logikáról áttér a szolgáltatáslogikára. Ellenkező esetben a szolgáltatások beáramlása a termelővállalatokhoz éppen ellenkező hatást fog kiváltani, s nem növeli a vevői elégedettséget, hanem csökkenti.

Ennek fényében a következőkben szeretnénk bemutatni azokat a legfontosabb szolgáltatáskutatási irányokat, amelyeket a világ vezető kutatói és gyakorlati szakemberei megfogalmaztak, majd ezek közül hármat kiválasztva prezentáljuk a témához kapcsolódó kutatási eredményeket és a kutatók, illetve a szakemberek elött álló kihívásokat.

\section{A szolgáltatásmarketing aktuális kérdései}

A szolgáltatások gazdasági jelentőségének növekedésével a szolgáltatásmarketing mint önálló diszciplína is az érettség szakaszába jutott egy képzeletbeli termékéletciklus-görbén. Ilyenkor jön el annak az ideje, hogy a terület kutatói végiggondolják, hogy hol tart a tudományterület és milyen kutatási prioritások fogalmazhatóak meg az elkövetkező időkben.

\section{A szolgáltatások kutatásának főbb irányai}

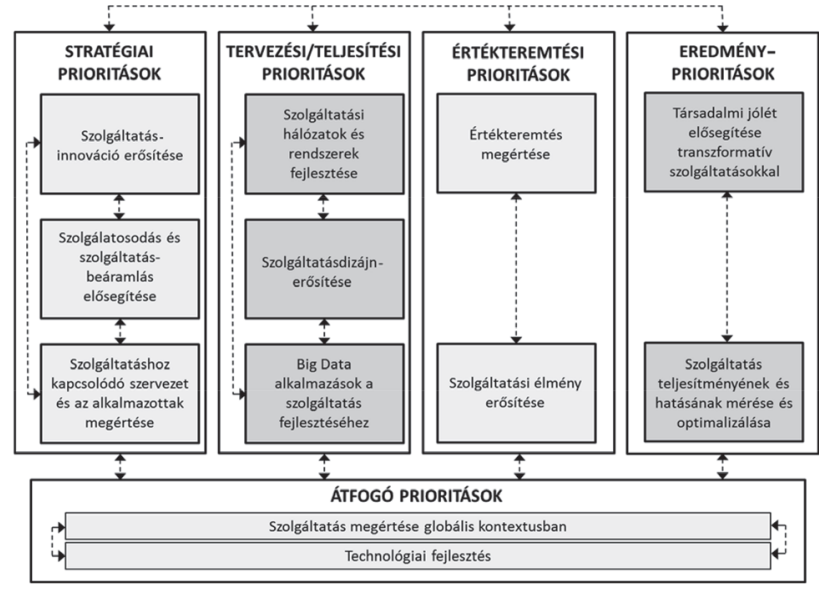

Forrás: Ostrom et al. (2015, 3. oldal)

Ostrom és szerzőtársai 2010-ben, majd 2015-ben egy nemzetközi kutatásra alapozva tíz olyan területet neveztek meg, amelyekre vonatkozóan fontos lenne további ismeretekhez jutni (Ostrom et al., 2010; Ostrom et al., 2015). A 
tíz területet nem prioritási sorrendben mutatjuk be, hanem a szerzők által meghatározott keretben, amely a stratégiai szempontokat, a tervezési szempontokat, az értékalkotási szempontokat és a kimeneti prioritásokat határozza meg. Az 1. ábra ebben a keretben mutatja be a legfontosabb kutatási irányokat.

Jelen cikkünkben három kutatási irányt mutatunk be, egyet-egyet a stratégiai, az értékteremtési és az outputprioritások közül. Választásunk bizonyos szempontból önkényes, hiszen mind a tíz területet fontosnak tartjuk, azonban terjedelmi korlátok miatt jelen cikkben elsősorban azokra a területekre fókuszálunk, amelyek kutatására vonatkozóan vannak magyar eredmények, illetve valamilyen módon csatlakozni tudunk már meglévő kutatási irányokhoz.

Elsőként a szolgáltatásélmény szerepével foglalkozunk. A szolgáltatásélmény, felfogásunk szerint, a szolgáltatás előállításának és teljesítésének valamennyi aspektusát foglalja magában, és jellemzően a fogyasztó holisztikus érzékelésén alapul. Nem választható el a szolgáltatásminőség koncepciójától, amely az elmúlt néhány évtized meghatározó kutatási irányzata volt a szolgáltatásmarketing diszciplínán belül. A szolgáltatásélmény mintegy kitágítja e gondolatkört és olyan kérdésekre is keresi a választ, hogy mi lehet a vevő szerepe a szolgáltatásteljesítés során, hogyan növelheti a co-creation a szolgáltatásélményt, alkalmazható-e a design-gondolkodás a szolgáltatási környezet megteremtésére. A szolgáltatási folyamat, azaz a fogyasztói utazás (consumer journey) lépésről lépésre történő megtervezése kiemelt fontosságú, hiszen ez ad segítséget a vevő konkrét élményének a megértéséhez.

Másik kiemelten fontos kérdéskörnek tekintjük az innovációt, azon belül is a technológia szerepét. Az önkiszolgáló technológiák (SST) alkalmazása egész iparágakat alakított át (például a turizmust, a pénzügyi szolgáltatásokat). Az új technológiák elterjedése, fogyasztói elfogadása fontos kihívás a szolgáltatóvállalatok számára. Kevéssé kutatott, de ígéretes lehetőség az okos szolgáltatások vizsgálata (smart services), amelyek egy intelligens eszköz segítségével folyamatos kommunikációra és interaktív viszszajelzésre adnak lehetőséget (például egészségi állapot nyomon követése).

Ehhez kötődik harmadik témánk, a transzformativ szolgáltatások területe. A transzformatív szolgáltatások kutatása a hazai marketingkutatásban még kevésbé jelent meg, noha egyre nagyobb érdeklődés övezi a nemzetközi szakirodalomban. Ez a kutatási terület a szolgáltatások és a társadalmi/egyéni jóllét közötti kapcsolatot vizsgálja. Kiemelt kontextusnak számít az egészségügy és az oktatás: hogyan lehet ezek minőségét és az emberek hozzáférését javítani ezekhez a szolgáltatásokhoz? Hogyan lehet a szolgáltatások nyújtásánál a fenntarthatósági szempontokat érvényesíteni? A transzformatív szemléletmód középpontjában állhat az egyén és a közösség is, hiszen a szolgáltatások fogyasztói gyakran kiszolgáltatottak, hátrányos helyzetben lehetnek a tapasztalatuk és tudásuk hiányában, különösen egyes csoportjaik (például idősek).

\section{A szolgáltatásélmény}

A szolgáltatások kutatásában és gyakorlatában a 80-as, 90es években a szolgáltatásminőség és az elégedettség volt a középpontban. A diszkonfirmációs paradigmára támaszkodva számtalan kutatás született a koncepcionalizálással (Parasuraman et al., 1985; Grönroos, 1984) és a szolgáltatásminőség mérésével kapcsolatban (Cronin - Taylor, 1992; Cronin - Taylor, 1994). A hazai marketingkutatásban is több kutató foglalkozott a szolgáltatásminőség kérdéskörével, a különböző iparági alkalmazásokra, a mérési dilemmákra és a koncepcionális vonatkozásokra is találhatunk kutatásokat ( Kenesei - Szántó, 1998; Fojtik - Farkas, 2001; Papp - Rózsa, 2003; Hetesi, 2003; Veres, 2008). A 2000-es évektől kezdődően a vevői élmény fogalma került az érdeklödés középpontjába. E váltásnak több oka is van: egyrészt a szolgáltatások komplexitása nőtt, ma már a szolgáltatások megítélését nem az egyes tranzakciók alakítják, hanem a szolgáltatási rendszer (service systems, Maglio et al., 2009) egésze, amellyel több csatornán is kapcsolatba kerülhet a fogyasztó. A vevő és a vállalat kapcsolata egyre kevésbé vizsgálható egy pillanatfelvételként, hanem annak időbeni alakulása és dinamikája is egyre fontosabbá válik. Ezt írja le a vevői utazás (customer journey) fogalma, amely felhívja a figyelmet arra is, hogy az igény felmerülésétől a vásárlás utáni magatartásig a vevő számtalan találkozási ponton (touch point) kerül kapcsolatba a szolgáltatóval, amelyek egy részét tudja kontrollálni a szolgáltató, más részét viszont nem (Rangaswamy - VanBruggen, 2005; Neslin et al., 2006).

\section{A szolgáltatással való találkozástól a szolgáltatási ökoszisztémáig}

A vevő és a vállalat kapcsolatának átalakulását, annak dinamikus jellegét fogalmazzák meg Akaka és szerzőtársai (2013), amikor azt javasolják, hogy a szolgáltatás kontextusát tágabban kell értelmezni. A szolgáltatáskutatás korábbi időszakában a szolgáltatással való találkozás (service encounter) jelentette a szolgáltatás fö kontextusát. Surprenant és Solomon (1987, 87. oldal) így határozták meg ennek jelentőségét:

\section{"A szolgáltatással való találkozás egy diadikus in- terakció a vevő és a szolgáltatásnyújtó között. Ennek az interakciónak a jellege határozza meg az elége- dettséget."}

Ahogy a szolgáltatással való találkozás fogalma elfogadottságot nyert, egyre inkább elkezdtek foglalkozni a kutatók a szerepek jelentőségével (Solomon et al., 1985). A fogyasztók egymással való interakciója jelenik meg a már minden szolgáltatásmarketing tankönyvben szereplő Servuction modellben is (Langeard et al., 1981), amely a szolgáltatók számára három fö területet jelöl ki, amellyel befolyásolhatják a végső szolgáltatáselőnyt: emberierőforrás-menedzsment, megfogható elemek és folyamatmenedzsment. Ehhez kapcsolódik egy külső tényező, amellyel azonban minden szolgáltatónak szükséges foglalkoznia, a szolgáltatás során jelen lévő többi 
vevő. Szintén nagy hatást gyakorolt Bitner és szerzőtársai (1990) munkája is, akik a szolgáltatással való találkozás vizsgálatára a kritikus esetek (CIT - critical incident technique) módszerét alkalmazták. E megközelítés több hazai marketingkutatásban is megjelent: Kolos (2004) például a légiutas-szállítás során fellépő interakciókat vizsgálta a kritikus esetek módszerével, és kutatási eredményei az emóciók jelentőségére hívták fel a figyelmet.

A szolgáltatáskontextus kibővítésének második fontos mérföldköve a fizikai és társadalmi tér bekapcsolása, amely a Servicescapes modellben fogalmazódott meg elöször (Bitner, 1992), mely szerint az ingerek nemcsak a vevőkre, hanem az alkalmazottakra is éppen annyira hatnak. Mi több a fogyasztó közvetlen belső reakcióit három nagy csoportba lehet sorolni: érzelmi, kognitív és fiziológiai reakciók. A további változást a már bemutatott közös értékalkotás (co-creation) gondolatkör megjelenése készítette elö, amely mára nemcsak lehetőség lett, hanem fontos vevői elvárás.

A közös értékalkotás egy megvalósulását vizsgálták McColl-Kennedy és szerzőtársai (2012). Kutatásukban azt elemezték, hogy az egészségügyi szolgáltatások terén ténylegesen hogyan érvényesül a közös értékalkotás. Nyolc főbb viselkedéscsoportot azonosítottak: együttmüködés, információgyüjtés, terápiák kombinálása, együttes tanulás (tudatos információkeresés és megosztás), kapcsolattartás családdal, barátokkal, orvosokkal és támogatócsoportokkal, életmódváltás, együttes alkotás (a kezelések megtervezése, átalakítása), érzelmi munka. Eredményeik szerint a betegek különböznek abban, hogy mennyire vesznek részt a tevékenységekben, ezekre mennyi energiát fordítanak.

Másrészt a szolgáltatásdomináns logika megfogalmazása is a servicescape fogalmának újragondolására késztette a kutatókat. Az S-D logika a szolgáltatási kontextust egy konkrét időintervallumtól vagy fizikai tértől függetlenül határozza meg, amely túlmutat a vevők és az alkalmazottak közötti közvetlen interakciókon. Így jutunk el a szolgáltatási ökoszisztéma (service ecosystems) fogalmához (Vargo et al., 2015). E felfogás szerint a szolgáltatás kontextusát és a közös értékteremtést az operáns erőforrások (pl. tudás és képesség) cseréje alakítja a szolgáltatási hálózatot alkotó szereplők és intézmények között.

A szolgáltatások kontextusának változása tehát a vevői szerepkör változásával áll leginkább összefüggésben. Ezt a közös értékalkotáson túl a vevői részvétel (customer participation - CP) fogalma is megragadja. Dong (2015) ennek két aspektusát is megkülönbözteti: a vevői részvétel mint előállító (CP as producers) és mint tervező (CP as designers). Az előbbi esetben a fogyasztó, mintegy az alkalmazott szerepkörét veszi át, és fizikai értelemben járul hozzá a szolgáltatáshoz, míg a másik esetben részt vesz a szolgáltatás egészének vagy egyes elemeinek kialakításában, vagy egyénre szabásában. Kutatási eredményei szerint a fogyasztók ez utóbbit részesítik előnyben, illetve jelentős azoknak az aránya is, akik semmiféle részvételt nem kedvelnek. A vállalatok számára fontos kérdés, hogy milyen jellegü és mértékű vevői részvételt tervezzenek, ehhez pedig jól kell ismerniük a fogyasztók motivációit.

\section{A vevői élmény fogalma}

A korai munkákban a vevői élményt a hedonikus fogyasztással hozták összefüggésbe, amely során egy rendkívüli tapasztalatot próbáltak a kutatók megragadni. Ma már ennél szélesebb kontextusban beszélünk a vevői élményről, ahol a vevő mint „használó”, „résztvevő”, „,együttalkotó” vagy „szereplö” jelenik meg ( McColl-Kennedy et al., 2015).

Meyer és Schwager (2007) nevéhez füződik a vevői élmény széles körben elfogadott meghatározása: eszerint vevői élménynek tekinthető a vevő belső, szubjektív válaszreakciója, amelyet a vállalattal való direkt vagy indirekt interakciók generálnak. Direkt kapcsolatnak tekinthető a szolgáltatás vásárlását és használatát jellemző minden olyan kapcsolat, amelyet a fogyasztó elöre megtervez. Ezzel szemben akkor beszélünk indirekt interakcióról, ha az a szolgáltató által nem kontrollálható körülmények között jön létre, és a fogyasztó sem tervezi meg elöre ezt az interakciót. Ilyen például a reklámmal való konkrét találkozás, egy e-mail érkezése vagy a közösségi hálón a vállalatról érkező más fogyasztói reakciók elolvasása. Némileg hasonló meghatározást adnak Gentile és társai (2007), amikor vevői élménynek nevezik azokat a reakciókat, amelyek a vevő és a termék, a vállalat vagy a vállalat képviselöi közötti interakció révén keletkeznek. Ezen élmény kialakulásának feltétele a vevő érdekeltsége, és jellemzően nagyon személyes formát ölt, hiszen a fogyasztó racionális, emocionális, érzékszervi, fizikai és spirituális módon vesz részt a fogyasztásban. A szolgáltatásminőség felfogásához hasonlóan a vevőnek az élményekkel kapcsolatban is lehetnek elözetes elvárásai, amelyeket összevet a különbözö találkozási pontokon (touch point) az öt ért tapasztalatokkal. A vevői élmény fontos jellemzője a holisztikus jelleg, azaz a vevő nem részleteiben, hanem egészében véve értelmezi az élményt, amelynek középpontjában a személy, az ember áll, aki szubjektíven érzékeli az őt körül vevő ingereket. Nagy jelentősége van a konzisztenciának is, a vevői élmény akkor marad meg a fogyasztó emlékezetében, ha az interakció valamennyi pontján ugyanazt a maradandó élményt kapja (Lemon Verhoef, 2016).

A vevői élmény vizsgálata különösen nagy hangsúlyt kap a turizmusban és a kultúra terén. Zátori (2013) például kutatásában kimutatta, hogy a turisztikai szolgáltatások élménytartalmát meghatározza az interakció, az élménykörnyezet, a személyre szabhatóság. Az élménybe való bevonódás pedig hat az élmény emlékezetességére és autentikusságára. Az élmény mértékét és sikerét leginkább a szolgáltató-vendég közti kapcsolat minősége és a turista élménybefogadásra való képessége és hajlandósága határozhatja meg (Kulcsár, 2015).

Pavluska Valéria (2014) kultúramarketinggel foglalkozó müve is középpontba helyezi az élmény fogalmát. Megállapítja, hogy a szolgáltatószektorban az élmény két módon jöhet létre. Az egyik esetben a szolgáltatás lényegi eleme az élmény, a másik esetben az alapszolgáltatáshoz társul az élmény. Érdekes kérdés, hogy az élményjavak, mint a kultúra, esetében van-e egyáltalán értelme élményesítésről beszélni, hiszen itt az emberek eleve elvárják 
az élvezeti értéket, az esztétikai és intellektuális hatást. A színházi előadás vagy a koncert is lehet ugyanakkor unalmas, egysíkú, ami jelzi, hogy a kulturális szolgáltatók is alkalmazhatják a vevői élmény alapelveit, például a sokérzéki hatás érvényesítésével, az élmény tematizálásával (például a történetmesélő cirkusz) vagy az együttalkotással (improvizációs színház).

Fontos megemlítenünk a játékosítás (gamification) szerepét is. Ezt úgy határozhatjuk meg, mint a játékelemek alkalmazását nem játékjellegü kontextusban (Deterding et al., 2011). A játékosítás jelentősége például a felsőoktatásban is megmutatkozik. Az oktatás szinte valamennyi eleme, az órák menete, a számonkérés, az otthoni tanulás vagy akár a teljes kurzus játékosítható, megteremtve ezzel a hallgatók hatékonyabb bevonását (Kenéz, 2016). A játékosítás fontos eszköz lehet a vevői elkötelezettség megteremtésében. Nagy kihívás a vállalatok számára, hogy ezt hogyan integrálják a szolgáltatási rendszerbe, hogy az ne öncélú legyen, hanem valóban a lojalitást és a kapcsolatok erősítését szolgálja (Harwood - Garry, 2015).

\section{A technológiavezérelt szolgáltatásinnovációk}

A szolgáltatások innovációja a szolgáltatások megfoghatatlan és elválaszthatatlan természeténél fogva kihívást jelent a vállalatok számára. A szolgáltatásinnovációk sokkal kevésbé kidolgozott folyamatokkal rendelkeznek és sokkal kevésbé tesztelhetők (Thomke, 2003). Ehhez kapcsolódik, hogy a modern, szolgáltatási ökoszisztémákban bonyolult folyamattá válik egy-egy innováció kialakítása (Vargo et al., 2015). A szolgáltatásrendszerek és az összekapcsolódó platformok, interfészek komplex kihívás elé állítják a szakembereket. Fontos figyelembe venni, hogy a folyamatos megújulás a versenyképesség fenntartásának egyik legfontosabb eszköze a szolgáltatóvállalatok számára is. Mivel az innováció legfontosabb hajtóerejét a technológiai fejlődés adja, ezért ebben a részben elsősorban a technológiavezérelt innovációkkal foglalkozunk. Mindazonáltal meg kell említenünk, hogy az innovációs folyamat kiemelt területe az innováció forrásának megváltozása: mára egy olyan többszereplős tevékenységgé vált az innováció, amely révén a nyílt innováción vagy a crowdsourcing-on keresztül akár külső szereplők is részesévé válhatnak a mindezidáig szigorúan belső vállalati tevékenységnek. Felmerül a kérdés, hogyan lehet hatékonyan felhasználni a vevői bázis innovativitását a különféle tömeges ötletgyüjtés, vagy más közös értékteremtésen alapuló megoldásokkal (az elöbbiekben már említett $\mathrm{CP}$ as designers). A vevői tudás és erőforrás felhasználása különösen aktuális kérdéssé vált napjainkra.

Minél erőteljesebben bevonjuk vevőinket a folyamatokba, annál erősebben jelenik meg az a kérdés, hogy „vajon elég jól képzettek-e a vevőink?” Ezzel a kissé provokatív kérdéssel nyitotta meg John Bateson azt a vitát, amely a vevők szerepéről szól a szolgáltatások előállítása során (Bateson, 2002). A vevői részvétel az előzőekben bemutatott közös értékteremtés (co-creation) eszméjének elterjedésével általánosan elfogadottá és elvárttá vált.
Felmerül azonban a kérdés, hogy vajon a vevők, akiknek részt kellene venniük a saját igényeiket szolgáló termék előállításában, vajon eléggé képzettek-e, vajon tudják-e, hogy mi a dolguk az értékteremtési folyamaton belül? Ez a kérdés különösen adekvát lett az önkiszolgáló technológiák széles körü elterjedésével.

Mills és Morris (1986) a vevőket „részfoglalkozású alkalmazottaknak" nevezik, utalva arra a tényre, hogy a vevők sokszor helyettesítik, kiváltják az emberi erőforrást, így átvitt értelemben a vállalat munkatársaivá válnak. Ilyen minőségükben elősegíthetik a vállalat hatékony müködését és egyúttal növelhetik saját elégedettségüket (Veres, 2009). A „,vevő mint vállalati erőforrás” koncepciója Vargo és Lusch (2004a) SDL-elméletével vált végleg elfogadottá. Ebben az értelmezésben a vállalat szerepe nem az érték teremtése (előállítása), hiszen a vevő lesz az, aki az értékteremtési folyamatban az előállító szerepét tölti be, a vállalat csupán segítője az értékteremtésnek (Grönroos, 2011). A vállalat és a vevő közös értékteremtésének számtalan vonulata fedezhető fel a szakirodalomban, de ha az erőforrás-elmélet oldaláról tekintünk a folyamatokra, akkor láthatjuk, hogy a vevő mint erőforrás sokféleképpen integrálható a vállalati folyamatokba. Tekinthetünk a vevöre mint emberi erőforrásra (vevő, aki elvégzi a banki müveleteket az interneten), mint tárgyi eszközre (vevő tulajdona, pl. otthon a számítógépe, amelyen bankol), vagy immateriális eszközre (vevő tudása, pl. ismeri és tudja használni az online banki rendszert). Ahhoz azonban, hogy ezeket az erőforrásokat integrálni tudjuk az értékteremtési folyamatba, szükséges, hogy a vevő rendelkezzék azokkal a képességekkel, amelyekkel a valóságos munkavállalók rendelkeznek, akik helyett „dolgozik”. Talán meglepő ez a végkövetkeztetés, de több kutató is felhívja a figyelmet annak a veszélyére, ha a vállalat nem teszi magáévá ezt a nézőpontot, és vevőit nem „képezi” a szükséges képességek és készségek elsajátítására (Hilton et al., 2013; Collier - Kimes, 2012). Ennek megfelelően szükséges, hogy a vállalat tisztázza és részletesen leírja azokat a szerepeket, amelyeket elvár a vevői részvétel során, hiszen ez által lesz képes hatékonyan integrálni, és a vevő elégedettségére kialakítani a folyamatokat. A megfelelő szerepek kialakításának fontossága kutatási eredményekkel igazolható (Kenesei, 2015). Abban az esetben, ha a vállalat jól kialakított és kommunikált szerepleírást ad vevőinek, hatékonyabban tudják majd használni az önkiszolgáló technológiát, könnyebben eligazodnak benne, és nagyobb élvezetet találnak a használatában. Mindez öszszességében erősíti az önkiszolgálás elfogadását és végső soron annak alkalmazását.

A technológiaalapú szolgáltatásinnovációk esetében megkerülhetetlen az innovációelfogadás folyamatának és az azt befolyásoló tényezőknek a vizsgálata. Ezen a téren számtalan kutatás és cikk készült az elmúlt évtizedekben, amelyek elsősorban a különféle önkiszolgáló technológiákhoz kötődő fogyasztói reakciókat vizsgálták. A kutatások elméleti alapját három nagyhatású irányzat adja meg: a rogersi (Rogers, 1995) innovációelfogadási folyamat (DOI - diffusion of innovations), a Davis (1989) által kialakított technológiaelfogadás modellje (TAM - 
technology acceptance model), illetve az eredetileg Ajzen és Fishbein (1980) által kialakított ,átgondolt cselekvés elmélete" (TRA - theory of reasoned action és az ezen alapuló TPB - theory of planned behavior). Ezeken a leginkább elfogadott elméleti kereteken kívül néhány kutató nem az elfogadást segítő tényezőkkel foglalkozik, hanem az elfogadást gátló tényezőket kutatja. Ezeket összességében „technológiahasználatot gátló tényezők” modelljének (ITU - inhibitors of technology usage) nevezik, és az eredményeik alapján a személyes kapcsolat hiánya, a bizalom hiánya és a biztonságosság érzetének a hiánya gátolja meg az embereket az önkiszolgáló technológiák használatában (Cenfetelli - Schwartz, 2011).

A szolgáltatáskutatásban legelfogadottabb modellé a TAM-modell vált, ez alapján az önkiszolgáló technológiák elfogadásának legfontosabb tényezői a használat egyszerüsége és a használhatóság, azaz a használatból származó előnyök összessége tekinthető. Ehhez kötődően azonban több kutatásban is felmerül a használat élvezetessége (Dabholkar - Bagozzi, 2002), mint fontos kiegészítője a modell változóinak. Ez kapcsolódik az előzőekben bemutatott szolgáltatásélmény fogalmához. A technológiának éppen úgy, mint az összes többi touch point-nak rendelkeznie kell az élményszerüséggel, hiszen csak ekkor számíthat arra a vállalat, hogy a vevő elfogadja és szívesen használja a felkínált önkiszolgáló alternatívát.

Az önkiszolgáló technológiáknak számtalan olyan előnyük van, amelyeket a fogyasztók maguk is észlelnek. A kutatási eredmények alapján elmondható (Kenesei Janecskó, 2015), hogy a legfontosabb ezek közül az, hogy a fogyasztó úgy érzi, jobb alternatívát jelent az önkiszolgálás, mint a szolgáltatón keresztüli személyes ügyintézés. Ennek hátterében sokszor az a tényező áll, hogy könynyebbnek, időtakarékosabbnak érzékelik, ha saját maguk végzik el a müveleteket, mintha egy ügyintéző. Néhányan kifejezetten kerülik a személyes interakciót. Sok esetben nemcsak az időmegtakarítás, hanem a költségcsökkentés is szerepet játszik a fogyasztói döntésben, bár el kell mondani, hogy ilyenkor nem biztos, hogy valós elfogadásról van szó. Ehhez kapcsolódik az a kérdés, hogy mennyire érdemes rákényszeríteni a vevőket az önkiszolgálás használatára akár valóságosan (minden más alternatívát megszüntetek, lásd BKK-pénztárak bezárása) vagy pénzügyi ösztönzőkkel (a személyes kiszolgálást felárazom). Erre vonatkozóan a kutatási eredmények azt igazolják, hogy a vevőkre rákényszerített használat csökkenti a technológia iránti bizalmat és növeli a technológiával szemben meglévő ellenállást (Liu, 2012). Fontos megemlíteni, hogy nemcsak a technológiához kötődő tényezőktől függ a fogyasztói elfogadás, hanem magától a fogyasztótól is. Ezt méri a Parasuraman (2000) által kifejlesztett mérőeszköz, a technológia-készenlét skálája (Technology Readiness TR), amely az optimizmus, az innovativitás, a diszkomfort és a bizalmatlanság dimenziókat foglalja magában.

Ígéretes kutatási területnek tartjuk az okos szolgáltatások (smart services) témáját (Wuenderlich et al., 2015). Az okos szolgáltatás egy olyan szolgáltatás, amelyet egy okos eszközön keresztül nyújtanak, képes a környezetét érzékelni, valósidejü adatot gyüjteni, folyamatos kommuniká- ciót fenntartani a felhasználóval és számára visszajelzést adni (például egészségmonitoring). A téma akadémiai kutatása azonban még gyerekcipőben jár. Keveset tudunk arról, hogy milyen üzleti modellek szükségesek ahhoz, hogy az okos technológiából okos szolgáltatás legyen, hogyan hat az okos szolgáltatás a fogyasztók viselkedésére, milyen tényezők határozzák meg fogyasztói elfogadásukat? Feltehetőleg az észlelt kockázat és a kontrollálhatóság meghatározó szerepet játszhatnak az okos szolgáltatások elterjedésében.

\section{A szolgáltatások és a jóllét kapcsolata}

A szolgáltatások meghatározóak a fogyasztók mindennapi életében: nap mint nap kapcsolatba kerülnek valamilyen szolgáltatóval legyen szó egy bankról, étteremről, oktatási vagy egészségügyi intézményről. Az, hogy ezek az interakciók hogyan mennek végbe, egyáltalán a fogyasztó hozzáfér-e megfelelö színvonalú szolgáltatáshoz, közvetlen összefüggésben állnak az egyén és a társadalom, illetve a társadalom egyes csoportjainak jóllétével. A jóllét fogalma utal arra, hogy a társadalom tagjai hogyan értékelik mindennapjaik minőségét, életkörülményeiket, milyen a közérzetük. Nem azonos a társadalmi jólét fogalmával, ami egyrészt hangsúlyosan az objektív anyagi mutatókat foglalja magában és a népesség egészére vonatkozik (KSH, A jóllét magyarországi indikátorrendszere, 2013). Bizonyos szolgáltatások kifejezetten hozzájárulhatnak az egyéni jólléthez, így hasznosságuk nemcsak gazdaságilag, de társadalmilag is értelmezendő (Michalkó - Rátz, 2013).

A szolgáltatások fogyasztói gyakran előnytelen helyzetben vannak, hiszen nem rendelkeznek hasonló szakértelemmel, mint a szolgáltatást nyújtó vállalat/szervezet és/ vagy a gazdaságpolitikai környezet kedvezőtlen alakulása érinti negatívan az egész szektort. E kiszolgáltatottság legföként a pénzügyi és egészségügyi szektorban jellemző. Számos hazai kutatás számol be arról, hogy a magyar lakosság pénzügyi kultúrája nem megfelelö (Zsótér et al., 2015; Kenesei, 2014). A Pénziránytű Alapítvány egy OECD-módszertanra támaszkodva végzett kutatást 2015ben. Az eredmények azt mutatják, hogy a válság elmúltával a lakosság pénzügyeit tekintve kevésbé megfontolt, gondos és elörelátó lett. Csupán minden negyedik család készít költségvetést és a megkérdezettek mintegy felének vannak pénzügyi céljai, ami alacsony értéknek tekinthető.

$\mathrm{Az}$ egészségügyi ellátás krónikus problémái (egészségügyi dolgozók túlterheltsége, anyagi megbecsülésük hiánya, az ellátáshoz való hozzáférés, hálapénz, egészségügyi dolgozók elvándorlása stb.) is nehezíti az egészségügyi szolgáltatásokhoz való megfelelő szintü hozzáférést (Simon, 2010). Egy Szinapszis Kft. által végzett kutatás szerint 2015-ben mind az orvosok, mind az ellátottak úgy értékelték, hogy az egészségügy átalakítása során a betegek érdekeit, igényeit nem veszik figyelembe. Az orvosok úgy érzik, hogy nem jut megfelelő idejük és energiájuk sem nekik, sem a nővéreknek, hogy a szakmai optimumot nyújtsák (Szinapszis.hu, 2015).

E jelenségek világszerte arra ösztönözték a kutatókat a közelmúltban, hogy kutatásaikban a szolgáltatások tágabb 
hatásaival is kiemelten foglalkozzanak. Így jelent meg a szakirodalomban a transzformatív szolgáltatáskutatás fogalma (transformative service research, TSR). E fogalom úgy határozható meg mint egy olyan kutatási irányzat, amely az egyének és a közösségek jóllétének fejlesztését tüzi ki célul, a jelen és a jövő fogyasztóinak életminőségét kívánja jobbá tenni. Gyökerei a transzformatív fogyasztókutatáshoz és a társadalmi marketinghez kötődnek, és annak következményeit fogalmazzák meg a szolgáltatáskutatás számára (Anderson et al., 2013; Ostrom et al., 2010).

A TSR vizsgálati területe a fogyasztói és a szolgáltatói oldal közötti komplex kapcsolatrendszer. Ezt a kapcsolatrendszert egyrészt alakítja a szervezet, annak folyamatai, a kínálat és az alkalmazottak. A fogyasztói oldal vizsgálata több szinten is lehetséges. beszélhetünk egyéni, kollektív szintről és az ökoszisztéma szintjéről. A kapcsolatrendszer jóllétre gyakorolt hatását több mutatószám is jelzi; ilyen lehet például a szolgáltatáshoz való hozzáférés javulása, az egyenlő elbánás javulása, az egyéni boldogságérzés növekedése. Egyre fontosabb kérdésnek mutatkozik a makroszint vizsgálata is. Ennek fontosságát is jól jelzi, hogy Muhammad Yunus a mikrohitelek terén tett erőfeszítéseiért részesült Nobel-békedíjban 2006-ban.

A TSR megközelítéséből két szűkebb témakört emelünk ki. Elsőként a szegénység problémáját járjuk körbe a TSR fogalomrendszerével, ezt követően pedig az idősekkel kapcsolatos saját és más hazai és nemzetközi kutatásokról adunk képet.

\section{A szegénység és a szolgáltatások}

A szegénység valamennyi országot többé-kevésbé érintő probléma. Az Európai Unió által kidolgozott AROPE-mutatószám szerint, - amely három tényező együttes vizsgálatát foglalja magában: a jövedelemhiányon túl számba veszi az anyagilag elérhető javak körét, valamint a munkaerőpiaccal való kapcsolatot is - 2013-ban Magyarországon a teljes lakosság 31,1\%-át, azaz 3 millió 44 ezer embert érintett a szegénység (KSH, A háztartások életszínvonala, 2014).

A többgenerációs szegénységben élőket a szolgáltatási rendszer nem képes megfelelően ellátni. Gyakran kiszorulnak az oktatásból, az egészségügyi ellátásból, a közlekedésből, az energiaszolgáltatásból. A szegénységmérési mutatók szerint a szegény kategóriába tartozó fogyasztókat más kiadási szerkezet és viselkedési minták jellemzik az otthoni étkezés, a lakáskörülmények, az egészségügyi kiadások, valamint a közlekedés terén. A szegények általában ezekre kevesebbet költenek (Sharpe - Abdel-Ghany, 1999). A kiadási szerkezet eltolódása mellett más viselkedésbeli jellemzők is érintik a szolgáltatószektort. A kutatási eredmények azt is mutatják, hogy a szegényebb fogyasztók kevésbé tudják megteremteni az egyéni/családi létbiztonságuk feltételeit (például a megtakarítások, a biztosítások igénybevételével), ezért magasabb szintű streszszel kell megbirkózniuk (Alvitt - Donley, 1996). Ebből adódóan jellemző a rövid távú gondolkodás, a kiszolgáltatottság érzése és a kontroll hiánya: a szegény fogyasztók gyakran érzik úgy, hogy nem ők irányítják saját sorsukat, hanem külső hatásoknak vannak kitéve. Ezért alacsony a kezdeményező készségük és a kockázatvállalási hajlandóságuk. A szegényedés problémáját is hangsúlyozza Törőcsik (2016) a fogyasztói magatartás új tendenciáival foglalkozó tanulmányában. Megállapítja, hogy a marketingszakma nem szeret negatív jelenségekkel foglalkozni, így e kérdéskör inkább a szociológiai kutatásokban jelenik meg. Megítélésünk szerint a hazai marketingszakmában szükséges lenne e téren egy jelentős szemléletváltás.

E globális problémák a szolgáltatáskutatókat is mozgósítják. Fisk és hét további neves kutató (2016) egy tudományos felhívást tett közzé, amelyben felhívják a figyelmet arra, hogy a kutatók is sokat tehetnek a szegénység csökkentése érdekében. Különösen nagy hangsúlyt kellene kapniuk a kutatásokban a piramis alján élőknek (BoPBottom of the Pyramid). Itt több mint négymilliárd emberről van szó, akik kevesebb, mint napi kilenc dollárból tartják fent magukat (Prahalad, 2006; Arnold - Valentin, 2013). Az eddigi kutatások arra is rámutatnak, hogy téves sztereotípiák is múködnek a BoP népességgel kapcsolatban. Ezek az emberek nemcsak passzívan várnak a segélyekre, hanem gyakran új üzleti modellek és innovációk megalkotói, amelyekből a fejlett világ is tanulhat (Prahalad - Mashelkar, 2010). Gondoljunk az Aravind Eye Care vagy a Bharti Airtel példájára, amely vállalatok innovatív üzleti modellekkel érték el, hogy az alapvető szolgáltatások hozzáférhetőek legyenek a hatalmas népességet magában foglaló szegények számára is.

\section{Az idősek és a szolgáltatások}

A WHO számításai szerint 2050-re a világ 60 év feletti népességének aránya eléri a 22\%-ot, ez mintegy kétmilliárd embert jelent (KSH, Statisztikai tükör, 2014). Egy hazai 2004-es átfogó időskutatás-program keretében végzett felmérés arra az eredményre jutott, hogy az idős emberek életminősége függ (Keszthelyiné, 2004) koruktól és egészségi állapotuktól, háztartási viszonyaiktól (egyedül vagy házastársukkal, élettársukkal élnek, eltartottakról kell-e gondoskodniuk stb.), vagyoni és jövedelmi helyzetüktől, tágabb baráti és családi környezettől kapott anyagi és nem anyagi támogatásoktól, különböző társadalmi (karitatív, egyházi és egyéb civil) szervezetek által nyújtott lehetőségektől, a települések adta lehetőségektől (infrastrukturális kiépítettség, jövedelemkiegészítés lehetősége stb.). Az idősebb fogyasztók magatartásának életkorral összefüggő változásai érintik a döntési folyamatot, a memóriát, az információfeldolgozás jellemzőit (Yoon et al., 2005). Mindezek befolyásolják, hogy mennyiben tud egy idős fogyasztó élni a szolgáltatások adta lehetőségekkel.

Az idősek, noha heterogén csoportnak számítanak mind anyagi, mind fizikai lehetőségeiket tekintve, Magyarországon számos szolgáltatás esetében a kirekesztettek közé tartoznak. A nyugdíjas háztartások bevételeik jelentős részét fordítják a létfenntartásra, az egészséggel kapcsolatos kiadásokra, többségük számára egy egyhetes üdülés sem fedezhetö (KSH, Statisztikai tükör, 2014).

A transzformatív felfogás szempontjából az egyik alapvető fontosságú kérdés, hogy az idősebb emberek életminőségében milyen szerepet tölthetnek be a szolgáltatások. Mitev és szerzőtársai (2015) az idősek vallási 
élményeit a vallási turizmuson keresztül vizsgálták, mint sokszor az egyetlen lehetőség számukra a turisztikai szolgáltatások igénybevételére.

Más aspektusból vizsgálják az időseket a technológiaalapú szolgáltatások kutatói. A számítástechnika használatában az időseket egyrészt korlátozhatják az anyagiak, a tanulási korlátok (hajlandóság és képesség), a motiváció hiánya, az egészségügyi problémák (ízületi problémák billentyüzet és egér használata), a segítség hiánya. Mindezen nehézségek ellenére a nemzetközi kutatások szerint a számítógép-használatnak számos előnye van az idősebb fogyasztók számára. A számítógépek segíthetik az elszigetelten élö embereket abban, hogy társadalmi kapcsolatokat építsenek ki (Czaja et al., 1993; White et al., 1999). A virtuális közösségekhez való csatlakozás révén új kapcsolatokat, barátságokat alakíthatnak ki abban az életkorban, amikor erre már kevés lehetőség adódna (Kanayama, 2003). A számítógéphez kötődő tevékenységek szellemi stimulációt jelentenek idős korban (Eilers, 1989), élvezetes hobbit nyújtanak és növelik az önbizalmat (Timmerman, 1998).

A témakörben végzett kutatásaink szerint az internethasználatra jellemző, hogy az időskorúak információfeldolgozásának üteme és módja eltér a fiatalabb generációétól: nehezen kezelik a túlzott mennyiségü információt és többnyire ragaszkodnak a megszokott, bevett módszerek alkalmazásához. Internetező tudásukat, még a gyakorlottabbak is, kritikusan értékelik, más korosztályokhoz képest alacsonyabb szintünek tekintik. Az internetező kedvet ténylegesen befolyásolja a társadalmi dimenzió, megfigyelhető, hogy a környezet hatása (ismerősök, családtagok) erős motivációt jelent. Emellett fontos szerepet játszanak az emocionális tényezők: az idős emberek internettel kapcsolatos attitűdjeiket érzelmi tényezők erősen befolyásolják, mint például félelem a gép kezelésétől, a modern technika életformát megváltoztató hatásától (Kolos, 2010). Törőcsik (2003) a fogyasztói trendek vizsgálatánál külön fejezetet szentel a szenioroknak (még a korosztály elnevezése sem egyértelmű), és a szolgáltatások kapcsán kiemeli, hogy az idősebbek jobban kedvelik az idősebb frontszemélyzetet, mert türelmesebbnek, megértőbbnek tartják őket.

A szolgáltatásokhoz való hozzáférés mellett fontos kérdés az, hogy hogyan élik meg az idősek magát a szolgáltatás folyamatát. Grougiou és Pettigrew (2011) kutatásából például kiderül, hogy az idősek a szolgáltató kiválasztásánál előnyben részesítik az interperszonális kapcsolatokat, ezáltal is növelve a szolgáltatás emocionális hasznosságát szemben a funkcionális hasznossággal. Ez összefüggésben állhat néhány időskorhoz kapcsolódó eseményhez, mint a gyerekek önállóvá válása, nyugdíjazás. A szolgáltatások ebben az esetben az élet egyéb területén jelentkező társadalmi kontaktus hiányát pótolják.

Az elmúlt években a szakirodalomban érezhető egy határozott irányvonal, amely az idősebb fogyasztók magatartását idő és kontextus vonatkozásában vizsgálja (Moschis, 2012). E felfogás alapja a life-course paradigma. Ez egy multidiszciplináris felfogást tükröző gondolatrendszer, amelynek vannak pszichológiai, antropológiai, szociológiai és közgazdasági vonatkozásai is. E paradig- ma lényege, hogy az élet egy adott pontján vagy szakaszában az egyén viselkedése a korábbi élethelyzeteire való reakcióinak a függvényében alakul. Megítélésünk szerint a transzformatív szolgáltatáskutatás és a life-course paradigmának számos közös pontja van, hiszen ez utóbbi felfogás szerint is az idős fogyasztó megértésére kellene leginkább a hangsúlyt fektetni, és nem arra, hogy milyen marketingeszközökkel befolyásolható leginkább.

\section{Összegzés}

Tanulmányunkban a szolgáltatáskutatás egyik alapvető kérdéséhez kívántunk hozzászólni; van-e létjogosultsága továbbra is a szolgáltatásmarketingnek mint önálló diszciplínának. A szolgáltatásmarketing alapkoncepciót, mint például a HIPI-elvet, Servuction modellt sok kritika érte az elmúlt időben, hiszen a szolgáltatói szféra növekedése, sokszínüsége, a vevői szerepek változása más kihívások elé állítják a szolgáltatóvállalatokat ma, mint 20-30 évvel ezelőtt. Megítélésünk szerint a szolgáltatáskutatás képes alkalmazkodni az új kihívásokhoz legyen szó szolgálatosodásról, a játékosításról vagy az okos szolgáltatásokról. Reményeink szerint az olvasó azzal a gondolattal fejezi be cikkünk olvasását, hogy a szolgáltatásmarketing alapvetései és eszközrendszere nemhogy veszített volna relevanciájából, hanem éppen hogy fontosabbá vált, és számos további izgalmas kutatási lehetőséget kínál a tudományos kutatás számára.

\section{Jegyzet}

${ }^{1}$ Jelen cikkünk az MTA Gazdálkodástudományi Bizottság Marketing Albizottságának felkérésére született a szolgáltatásmarketing téma tudományos eredményeinek és jövőjének összefoglalására.

\section{Felhasznált irodalom}

Ajzen, I. - Fishbein, M. (1980): Understanding Attitudes and Predicting Social Behavior. Englewood Cliffs, NJ: Prentice Hall

Akaka, M. A. - Vargo, S. L. - Lusch, R. F. (2013): The complexity of context: a service ecosystems approach for international marketing. Journal of International Marketing, 21(4), p. 1-20.

Anderson, L. - Ostrom, A. L. - Corus, C. - Fisk, R. P. - Gallan, A. S. - Giraldo, M. - Mende, M. - Mulder, M. - Rayburn, S. W. - Rosenbaum, M. S. - Shirahada, K. - Williams, J. D. (2013): Transformative service research: An agenda for the future. Journal of Business Research, 66, p. 1203-1210.

Arnold, D. G. - Valentin, A. (2013): Corporate social responsibility at the base of the pyramid. Journal of Business Research, 66 (10), p. 1904-1914.

Alvitt, L. - Donley, T. (1996): The Low-Income Consumer: Adjusting the Balance of Exchange. London: Sage Publications

Bálint N. A. (2014): Szolgálatosodás Nyugat-Európában és Magyarországon. Hol tartunk és merre haladunk? Egy nemzetközi felmérés nyomán. Vezetéstudomány, 0133-0179. 2015. 46. évf. 5. szám, p. 24-33. 
Bateson, J. (2002): Are your customers good enough for your service business? Academy of Management Executive, 16(4), p. 110-120.

Berács, J. (2006): Oktatási hub a láthatáron - Logisztikai tapasztalatok tanulságai. Vezetéstudomány, 37, November, p. $2-11$.

Bitner, M. J. (1992): Servicescapes: The Impact of Physical Surroundings on Customers \& Employees. Journal of Marketing, 56(2), p. 57-71.

Bitner, M. J. - Booms, B. H. - Tetreault, M. S. (1990): The Service Encounter: Diagnosing Favorable and Unfavorable Incidents. Journal of Marketing, 54 (January), p. 71-84.

Cronin, J. J. Jr. - Taylor, S. A. (1992): Measuring service quality: a reexamination and extension. The Journal of Marketing, 56(2), p. 55-68.

Cronin, J. J. Jr. - Taylor, S. A. (1994): SERVPERF versus SERVQUAL: reconciling performance-based and perceptions-minus-expectations measurement of service quality. The Journal of Marketing, 58(1), p. 125-131. DOI: $10.2307 / 1252256$

Cenfetelli, R. T.- Schwarz, A. (2011): Identifying and Testing the Inhibitors of Technology Usage Intentions. Information Systems Research, 22(4), p. 808-823.

Collier, J. E. - Kimes, S. E. (2012): Only If It is Convenient: Understanding How Convenience Influences Self-Service Technology Evaluation. Journal of Service Research, 16(1), p. 39-51.

Czaja, S. J. - Guerrier, J. H. - Nair, S. N. - Landauer, T. K. (1993): Computer Communication as an Aid to Independence for Older Adults. Behavior and Information Technology, 12(4), p. 197-207.

Dabholkar, P. A. - Bagozzi, R. P. (2002): An Attitudinal Model of Technology-Based Self-Service: Moderating Effects of Consumer Traits and Situational Factors. Journal of the Academy of Marketing Science, 30(3), p. 184-201.

Davis, F. D. (1989): Perceived Usefulness, Perceived Ease of Use, and User Acceptance of Information Technology. MIS Quarterly, 13(3), p. 319-340.

Demeter, K. (2010): Szolgálatosodás, avagy az integrált termék-szolgáltatás rendszerek kialakulása és jellemzői. 124. sz. mühelytanulmány. Budapest: $\mathrm{BCE}$

Demeter, K.-Szász, L. (2012): Úton a megoldásalapú gondolkodás felé - szolgálatosodási jellemzők magyarországi termelővállalatoknál. Vezetéstudomány, 18(11), p. 34-45.

Deterding, S. - Dixon, R. - Khaled, R. - Nacke, L. (2011): Gamification: towards a definition. Mindtrek (http:/gamification-research.org/wp-content/uploads/ 2011/04/02-Deterding-Khaled-Nacke-Dixon.pdf)

Dong, B. (2015): How a customer participates matters: „I am producing” versus „I am designing”. Journal of Services Marketing, 29(6/7), p. 498-510.

Eilers, M. L. (1989): Older Adults and Computer Education: „Not to Have the World a Closed Door”. International Journal of Technology and Ageing, 2(1), p. 56-76.
Fisk, R. P. - Anderson, L. - Bowen, D. E. - Gruber, T. Ostrom, A. - Patrício, L. - Reynoso, J. - Sebastiani, $R$. (2016): Billions of impoverished people deserve to be betterserved. Journal of Service Management, 27(1), p. 43-55.

Fisk, R. P. - Grove, S. J. (2010): The evolution and future of the service: Building and broadening a multidisciplinary field. In: Maglio, P. P. - Kieliszewski, C. Spohrer, J. (eds.) (2010): Handbook of service science: Research and innovations in the service economy. New York: Springer, p. 643-663.

Fojtik, J. - Farkas, L. (2001): Minőség és marketing: a pénzügyi szolgáltatások példája. Vezetéstudomány, 32(10), p. 44-53.

Gentile, C. - Spiller, N. - Noci, G. (2007): How to Sustain the Customer Experience: An Overview of Experience Components that Co-Create Value with the Customer. European Management Journal, 25(5), p. 395-410.

Grougiou, V. - Pettigrew, S. (2011): Senior Customers' Service Encounter Preferences. Journal of Service Research, 14(4), p. 475-488.

Grönroos, C. (1984): A service quality model and its marketing implications. European Journal of Marketing, 18 (4), p. 36-44.

Grönroos, C. (2011): Value co-creation in service logic: A critical analysis. Marketing Theory, 11 (3), p. 279-301.

Harwood, T. - Garry, T. (2015): An investigation into gamification as a customer engagement experience environment. Journal of Services Marketing, 29 (6/7), p. 533-546.

Hetesi, E. (2003): A minőség, az elégedettség és a lojalitás mérésének problémája a szolgáltatásoknál és azok hatása a jövedelmezőségre. Marketing\&Menedzsment, 37(5), p. 42-50.

Hilton, T. - Hughes, T. - Little, E. - Marandi, E. (2013): Adopting self-service technology to do more with less. Journal of Services Marketing, 27(1), p. 3-12.

Kanayama, T. (2003): Ethnographic Research on the Experience of Japanese Elderly People Online. New Media and Society, 5(2), p. 267-288.

Kelemenné E. A. (2014): A közforgalmú közlekedési szolgáltatás és piac vizsgálata marketing és fenntarthatósági nézőpontból. Értekezés. Budapest: BME, p. 26-30.

Kenesei Zs. (2014): A pénzügyi kultúra fejlődése Magyarországon az elmúlt 15 évben. In: Sugatagi Gábor (szerk.): Gazdaság, társadalom, fogyasztás - 19892014. Budapest: GfK Hungária Piackutató Intézet, p. 138-195.

Kenesei Zsófia (2015): Good Enough Customers: Impact of Role Clarity in Self-Service Technologies. In: Luk Warlop (ed.): Collaboration in Research: EMAC 2015: 44th Annual Conference

Kenesei, Zs. - Szántó, Sz. (1998): A szolgáltatásminősítés mérése - elmélet és gyakorlat. Vezetéstudomány, 29(12), p. 8-18.

Kenesei Zs. - Janecskó E. (2015): Önkiszolgáló technológiák elfogadásának vizsgálata a szerepelmélet segítségével. Vezetéstudomány, 46 (1), p. 2-19. 
Kenéz, A. (2016): A játékosítás (gamification) a felsőoktatásban. In: Kozák, Á. - Fehér, A. - Kiss, V. Á. - Soós, M. - Szakály, Z. (szerk.): EMOK XXII. Országos Konferencia 2016 Tanulmánykötet: Hitelesség és értékorientáció a marketingben. Debrecen: Debreceni Egyetem, p. 275-280.

Keszthelyiné, R. M. (2004): Az időskorú háztartások fogyasztási színvonala és szerkezete (A KSH háztartási költségvetési felvételének adatai alapján). In: Giczi, J. - Sághi, G. (szerk.) (2004): Időskorúak Magyarországon. Budapest: KSH, p. 143-174.

Kolos, K. (2004): A szolgáltatásokkal való találkozás elemzése a légi utas-szállításban: a krtitikus esetek módszerének egy alkalmazása. In: Berács, J. - Lehota, G. - Piskóti, I. - Rekettye, G. (szerk.) (2004): Marketingelmélet a gyakorlatban. Budapest: KJK Kerszöv, p. 257-265.

Központi Statisztikai Hivatal (2013): A jóllét magyarországi indikátorrendszere. http://www.ksh.hu/docs/ hun/xftp/idoszaki/pdf/jollet13.pdf

Központi Statisztikai Hivatal (2014): Statisztikai Tükör http://www.ksh.hu/docs/hun/xftp/stattukor/idosek_vilagnapja_14.pdf

Központi Statisztikai Hivatal (2014): A háztartások életszínvonala http://www.ksh.hu/docs/hun/xftp/idoszaki/ hazteletszinv/hazteletszinv.pdf.

Kolos, K. (2010): Értékek, szerepek és életmód ötvenen túl. In: Corvinus Marketing Tanulmányok, 1. Budapest: BCE, p. 29-38.

Kulcsár, N. (2015): A fogyasztói érték és az élmény a turisztikai szakirodalomban. Vezetéstudomány, 46(3), p. 18-25.

Langeard, E. - Bateson, J. E. G. - Lovelock, C. H. - Eiglier, P. (1981): Services Marketing: New Insights from Consumers and Managers. Cambridge, MA: Marketing Science Institute

Lemon, K. N. - Verhoef, P. C. (2016): Understanding customer experience throughout the customer journey. Journal of Marketing, 80, 6, p. 69-96.

Liu, S. (2012): The impact of forced use on customer adoption of self-service technologies. Computers in Human Behavior, 28, p. 1194-1201.

Lovelock, C. - Gummesson, E. (2004): Whither Services Marketing? In Search of a New Pradigm and Fresh Perspectives. Journal of Services Research, 7(1), August, p. 20-41.

Maglio, P. P. - Vargo, S. L. - Caswell, N. - Spohrer, J. (2009): The Service System is the Basic Abstraction of Service Science. Information Systems E-Business Management, 7, p. 395-406.

McColl-Kennedy, J. R. - Vargo, S. L. - Dagger, T. S. Sweeney, J. C. - van Kasteren, Y. (2012): Health Care Customer Value Cocreation Practice Styles. Journal of Service Research, 15(4), p. 370-389.

McColl-Kennedy, J. R. - Gustafsson, A. - Jaakkola, E. Klaus, Ph. - Radnor, Z. J. - Perks, H. - Friman, M. (2015): Fresh perspectives on customer experience. Journal of Services Marketing, 29(6/7), p. 430 - 435.

Meyer, C. - Schwager, A. (2007): Understanding Customer Experience. Harvard Business Review, 85(2), p. 117127.
Michalkó, G. - Rátz, T. (szerk.) (2013): Jó(1)lét és turizmus: utazók, termékek és desztinációk a boldogság és a boldogulás kontextusában. Székesfehérvár - Budapest: Kodolányi János Főiskola, MTA CSFK Földrajztudományi Intézet; Magyar Földrajzi Társaság, 268.

Mitev, A. - Irimiás, A. - Michalkó, G. (2015): Halászkirályok hanghullámai - az idősek vallási eseményekhez kapcsolódó élményeinek megértése. Vezetéstudomány, 46(4), p. 26-34.

Mills, P. K. - Morris, J. H. (1986): Clients as "partial" employees of service organizations: Role development in client participation. Academy of Management Review, 11, p. 726-735.

Moschis, G. P. (2012): Consumer Behavior in later Life: Current Knowledge, Issues, and New Directions for Research. Psychology and Marketing, 29(2), p. 57-75.

Neslin, S. A. - Grewal, D. - Leghorn, R. - Shankar, V. Teerling, M. L. - Thomas, J. S. - Verhoef, P. C. (2006): Challenges \& Opportunities in Multichannel Customer Management. Journal of Service Research, 9(2), p. 95-112.

Ostrom, A. L. - Bitner, J. - Brown, S. W. - Burkhard, K. A. - Goul, M. - Smith-Daniels, V. - Demirkan, H. Rabinovich, E. (2010): Moving Forward and Making a Difference: Research Priorities for the Science of Service. Journal of Service Research, 13(1), p. 4-36.

Ostrom, A. L. - Parasuraman, A. - Bowen, D. A. - Patricio, L. - Voss, C. A. (2015): Service Research Priorities in a Rapidly Changing Context. Journal of Service Research, 18(2), p. 127-159.

Papp, K. - Rózsa, A. (2003): A szolgáltatásminőség elméletben és gyakorlatban. Marketing\&Menedzsment, 37(5), p. 4-13.

Parasuraman, A. (2000): Technology Readiness Index (TRI): A Multiple-Item Scale to Measure Readiness to Embrace New Technologies. Journal of Service Research, 2(4), p. 307-320.

Parasuraman, A. - Zeithaml, V. A. - Berry, L. (1985): A Conceptual Model of Service Quality and Its Implications for Future Research. Journal of Marketing, 49 (4), p. 41-50.

Pavluska, V. (2014): Kultúramarketing. Budapest: Akadémiai Kiadó

Pawar, K. S. - Beltagui, A. B. - Riedel, J. C. K. H. (2009): The PSO triangle: designing product, service and organization to create value. International Journal of Operations and Production Management, 29(5), p. 468- 493.

Pénzügyi Szemle (2015): Magyarok és a pénzügyi kultúra: "Tűzz ki pénzügyi célokat!" http://www. penzugyiszemle.hu/tanulmanyok-eloadasok/ magyarok-es-a-penzugyi-kultura-tuzz-ki-penzugyi-celokat

Prahalad, C. K. (2006): Esélyek a piramis alján. Budapest: HVG

Prahalad, C. K. - Ramaswamy, V. (2004): The Future of Competition: Co-Creating Unique Value with Customers. Boston: Harvard Business School Press 
Prahalad, C. K. - Mashelkar, R. A. (2010): Innovation's Holy Grail. Harvard Business Review, July-August, p. 132-141.

Rangaswamy, V. - Van Bruggen, G. H. (2005): Opportunities \& challenges in multichannel marketing: An introduction to the special issue. Journal of Interactive Marketing, 19(2), p. 5-11.

Rogers, E. M. (1985): Diffusion of Innovations. New York: The Free Press

Sharpe, D. L.- Abdel-Ghany, M. (1999): Identifying the Poor and Their Consumption Patterns. Family Economics and Nutrition Review, 12(2), p. 15-25.

Shostack, G. L. (1977): Breaking Free from Product Marketing. Journal of Marketing, 41, p. 73-80.

Simon, J. (2010): Marketing az egészségügyben. Budapest: Akadémia Kiadó

Solomon, M. R. - Surprenant, C. F. - Czepiel, J. A. - Gutman, E. G. (1985): A role theory perspective on dyadic interactions: the service encounter. The Journal of Marketing, 49(1), p. 99-111.

Surprenant, C. F. - Solomon, M. R. (1987): Predictability and personalization in the service encounter. The Journal of Marketing, 51(2), p. 6-96.

Szinapszis.hu (2015): Milyen a betegbiztonság 2015-ben Magyarországon? http://www.szinapszis.hu/kutatasi eredmenyek/123

Thomke, S. (2003): R\&D Comes to Services. Harvard Business Review, 81(4), p. 70-79.

Timmerman, S. (1998): The Role of Information Technology in Older Adult Learning. New Directions for Adult and Continuing Education, 77, p. 61-71.

Töröcsik, M. (2003): Fogyasztói trendek. Budapest: KJK Kerszöv

Töröcsik, M. (2016): A fogyasztói magatartás új tendenciái. Vezetéstudomány, 47(4), p. 19-29.

Vargo, S. L. - Lusch, R. F. (2004a): Evolving to a new dominant logic for marketing. Journal of Marketing, 68, (January), p. 1-17.

Vargo, S. L. - Lusch, R. F. (2004b): The Four Service Marketing Myths: Remnants of a Goods-Based, Manufacturing Model. Journal of Service Research, 6, p. 324-335.

Vargo, S. L. - Lusch, R. F. (2008): Service-dominant logic: continuing the evolution. Journal of the Academy of Marketing Science, 36(1), p. 1-10.
Vargo, S. L. - Lusch, R. F. (2016): Institutions and axioms: an ex- tension and update. Journal of the Academy of Marketing Science, 44(1), p. 5-23.

Vargo, S. L. - Wieland, H. - Akaka, M. A. (2015): Institutions in innovation: a service ecosystems perspective. Industrial Marketing Management, 44(1), p. 63-72.

Veres, Z. (2008): Egy régi mánia: A gap modell az elégedettségkutatásban. Marketing\&Menedzsment, 42(2), p. 4-17.

Veres Z. (2009): A szolgáltatásmarketing alapkönyve. Budapest: Akadémiai Kiadó

White, H. - McConell, E. - Clipp, E. - Bynum, L. - Teague, C. - Navas, L. - Craven, S. - Halbrecht, H. (1999): Surfing the Net in Later Life: a Review of the Literature and Pilot Study of Computer Use and Quality of Life. Journal of Applied Gerontology, 18(3), p. 358-378.

Wind, J. - Rangaswamy, A. (2001): Customerization: the next revolution in mass customization. Journal of Interactive Marketing, 15(1), p. 13-32.

Wuenderlich, N. V. - Heinonen, K. - Ostrom, A. L. - Patricio, L. - Sousa, L. - Voss, C. -Lemmink, J. G. A. M. (2015): „Futurizing” smart service: implications for service researchers and managers. Journal of Services Marketing, 29 (6/7), p. 442 - 447.

Yoon, C. - Laurent, G. - Fung, H. - Gonzales, R. - Gutches, A. - Hedden, T. - Lambert-Pandraud, R. - Mather, M. - Park, D. - Peters, E. - Skurnik, I. (2005): Cognition, Persuasion and Decision Making in Older Consumers. Marketing Letters, 16(3/4), p. 429-441.

Zátori, A. (2013): Turisztikai élményteremtés vizsgálata szolgáltatói szemszögből. Ph.D- disszertáció. Budapest: Budapesti Corvinus Egyetem, Gazdálkodástani Doktori Iskola

Zátori, A. (2014): Az élménymenedzsment koncepcionális alapjai. Vezetéstudomány, 45(9), p. 57-66.

Zeithaml, V. A. - Brown, S. W. - Bitner, M. J. - Salas, $J$. (2014): Profiting from services and solutions: What product-centric firms need to know (service systems and inovations in business and society). New York: Business Expert Press

Zsótér Boglárka-Béres Dániel-Németh Erzsébet (2015): A magyar fiatalok jellemzése pénzügyi attitüdjeik és magatartásuk mentén: Vizsgálat a felsőoktatásban tanulók pénzügyi attitüdjeiről és magatartásáról. Vezetéstudomány, 46:(6), p. 70-80. 